\title{
Globalization and Its Brunt on Nigeria Global Economic Competitiveness: The Need for Holistic and Dynamic Strategies
}

\author{
M. A. Obomeghie ${ }^{1}$ (D) , Ugbomhe O. Ugbomhe ${ }^{2}$ (D) \\ ${ }^{1}$ Department of Statistics, Auchi Polytechnic, Auchi, Edo State, Nigeria. \\ ${ }^{2}$ Department of Business Administration, Ambrose Ali University, Ekpoma, Edo State, Nigeria.
}

\begin{abstract}
Purpose of the study: The intensity of globalization has resulted in the near-collapse of most manufacturing industries in Nigeria. Most products from Nigeria industries lack the ability to compete with similar products from developed countries. Such appalling competitiveness of the Nigeria economy has bequeathed untold hardship on the citizens of Nigeria. The rationale for undertaking this study is to determine globalisation's brunt on Nigeria's economic competitiveness empirically.
\end{abstract}

Keywords:

Developing economies,

Economic

competitiveness,

Innovation,

Globalization, Nigeria.
Methodology: The Least Square method was employed to analyse the data collected from various statistical agencies such as the Nigeria statistical bulletin, World Economic Forum report and the United Nations Industrial Development report. The data collected is for the period spanning 2006 to 2017. Microfit 5.1 Statistical software is used in the analysis.

Main Findings: The findings of the study shows that there is a negative relationship between globalization and Nigeria global economic competitiveness. The results further indicate that Nigeria's participation in the global arena has not yielded the desired benefit associated with globalization with respect to the country's competitiveness.

Research limitations/implications: The study adds to earlier works on economic competitiveness as a sound pillar of globalization by carving out an empirical analysis of Nigeria experience with globalization. The implications of the study's findings show that Nigeria's innovation strategies significantly lag behind the innovation strategies in developed countries.

Received Date:

07-09-2020

Accepted Date:

20-01-2021

Publication Date:

30-03-2021
Novelty/Originality of this study: This work put-forward a useful awareness into the existential challenge facing Nigeria and other developing economies in terms of equal capacity to confront their developmental problems as a result of globalization. The study further provides a pathway for Nigeria's economic managers to overcome such challenges with dynamic strategies to achieve the desired benefits of globalization.

\section{INTRODUCTION}

Trade, communication and other forms of interaction between people from different parts of the world started more than a thousand years ago. The driving force for such interaction has mainly been trading, the quest to annex more territories, demand for labour, missionary activities etc. Such interaction laid the foundation for globalization as it is practised today; however, globalisation's renewed concept is increasingly hinged on trade and the need to have a peaceful and harmonious world. It has been observed that contrary to earlier insinuation that globalization will be mutually beneficial to all countries in the world, figures have shown that it has negatively impacted Nigeria's economic competitiveness. According to Konyeaso (2016), the Silk Road, which connected Asia, Africa and Europe, represent a perfect example of the foundation of modern globalization. Following the end of communism and the end of the cold war period, the world economy is increasingly and significantly driven by neoliberal economic policies that favour capitalism on a global scale through trade liberalization, foreign direct investment, and financial capital flow, as well as the relaxation of government regulations, especially in financial transactions (Umar, Hamidu, \& Musa, 2013).

In a recent study, Alleynea, Francis \& Best, (2016) noted that the term globalization is often described as a historical process that entails the increasing integration of/and interaction between countries as national borders become of lesser importance. In a similar vein, O'Rourke and Williams, (2001) and Maddison, (2001) noted that the globalization process grounded in the latter period of the 18th century entails economic, cultural, political and environmental integration. Other scholars have gone further to re-define the concept into both the politically centred and economically centred definition. For example, a politically centred definition by Schirato and Web (2003) suggests that globalization function as a set of texts, ideas, goals, values, narratives, dispositions and provisions, a veritable template for ordering and evaluating activities which are filled in or inflected with the interest of whoever can access it. On the other hand, the economically centred definition noted that globalization is essentially a much more material reality in the contemporary world.

Shamgquan (2000) defined economic globalization as the increasing interdependence of world economies as a result of the growing scale of cross-border trade on commodities and services, the flow of international capital and the rapid spread of

\footnotetext{
2 Corresponding Author: ugbomhe2017@gmail.com
}

Please cite this article as: Obomeghie, M. A. ., \& Ugbomhe, U. O. (2021). Globalization and Its Brunt on Nigeria Global Economic Competitiveness: The Need for Holistic and Dynamic Strategies. International Journal of Social Sciences and Economic Review, 3(1), 1-06. doi.org/10.36923/ijsser.v3i1.77 
technologies. It reflects the continued expansion and mutual integration of market frontiers, which is now an irreversible trend for economic development in the whole world. Based on the above deposition, the research problem undertaken in this study is to investigate the existential challenge facing Nigeria as a result of the continues loop-sidedness in global economic competitiveness, which will be appalling to Nigeria and other developing countries if not checked by appropriate financial strategies.

Consequently, our study's hypothesis states that there is no positive relationship between globalization and Nigeria's economic competitiveness in the global arena. Essentially, this study's motivation is hinged on the realization that the current globalization arrangement has failed the mutually beneficial test. In addition, the scenario portrays an ever-widening gap in the competitive abilities between developing economies such as Nigeria and the developed economies.

\section{LITERATURE REVIEW}

Globalization is an inevitable and irreversible phenomenon in human activities that have brought the world closer by exchanging goods and product, information, knowledge and culture. However, the process has been more beneficial to some nations (mostly developed countries). In contrast, the developing countries have obtained minimal economic benefit (if any) from the process because of such countries' uncompetitive nature. In this sense, Kendall (2008) observed that globalization is a process of continuous creative destruction in which uncompetitive countries fall further and further behind at an increasing pace with the unskilled and poor. On the strength of this study's reviewed literature, the hypothesis of this work posits that a negative relationship exists between globalization and Nigeria's global economic competitiveness.

Analyzing the relationship between globalization and a nation's economic competitiveness remains a field of concern to pro-globalization and anti-globalization policymakers and academics. Globalization proponents have shown that financial liberalization, trade openness and the influx of foreign direct investment are beneficial to all nations (Kumar \& Pradhan, 2002). Anti-globalization proponents argue that globalization is a system evolved and operated by the developed countries to rule the world economy by pushing the manufacturing industries of the developing countries out of production through unfair competition. Ayenagbo et al, (2012) argued that the adverse effect of trade liberalization has been severe in many African countries, citing a UNDP report (2002), they argued that 22 countries in Sub-Sahara African countries had lower per capita income in 2000 than they did in the period from 1975 to 1985 . According to the Schwab (2015), the global competitiveness index template concepts have the following pillars:

- Institution

- ICT adoption

- Macroeconomic environment

- Skills

- Product market

- Labour market

- Financial system

- Market size

- Business dynamics

- Innovation capacity

\subsection{Economic benefits and disadvantages associated with globalization}

It has been variously argued that globalization bequeath numerous economic benefits on all countries of the world, to this end, one can pointedly list the economic benefit the Nigeria economy may achieve from globalisation to includes the following.

- Increased specialization and efficiency.

- Quality of product at a reduced price.

- Economies of scale in production.

- Increased competitiveness and increase output.

- Technological improvement and increase managerial capabilities.

- Trade and investment can boost efforts at restructuring the economy to make it more competitive and better-off.

- Communication and mass media have the traditional function of multiplying mobility and facilitate the exchange of information about goods and services.

- Exhibition trade fair and media advertising which can help in the marketing of goods services.

- The modern banking system, through electronic banking and automatic teller machines etc., makes trade much easier.

- Email and text messages have replaced posting of letters, online registration of examination, etc. making business communication easy.

In the same vein numerous economic disadvantages associated with globalization, to a large extent, have driven Nigeria economy to the gallows with very slim chances of recovering. Specifically, developing countries such as Nigerians have faced the following pitfalls as a result of globalization despite the perceived enormous benefits.

- In most cases, globalization has caused developing countries like Nigeria to live at the mercy of the developed countries in terms of economic manipulation.

- It undermines national economic and political independence and creates, to some extent, international disparities. 
- Trade regime in advanced economies generally discriminates against the goods that developing countries produce, e. g. food, textile, clothing etc.

- European colonialism and neo-colonization have lead to global capitalist exploitation, and their ruthless extraction of resources from developing countries has been on the increase.

- Policies of deregulation, privatization and commercialization by the International Monetary Fund (IMF), the World Bank and the World Trade Organization (WTO) do not consider the economic peculiarities of developing countries like Nigeria.

- The envisaged technology transfer has been an illusion because the developed world's advanced technologies are kept secret instead of being given to the developing countries. This has lead to the low competitiveness of developing countries.

- The balance of payment position of developing countries has been adverse because there is massive importation of electronic, communication and military gadget without commensurate export by developing countries.

- There is a loss of biodiversity because agricultural products directly affect any country's economic status; the impact of globalization has had a bad influence on Nigeria's wide variety of plants.

\subsection{Nigeria Global Economic Competitiveness.}

International or global economic competitiveness may be seen as the degree to which a country can, under free and fair market condition, meet the international market test while simultaneously maintaining and expanding the real income of its citizens (Kharlamova \& Vertelieva, 2013). Schwab (2017) defines competitiveness as the country's ability and institutions to ensure stable economic growth in the medium term. By 2018 the World Economic Forum report ranked Nigeria 115 out of 140 countries in the global competitive index, indicating a three-point increase from 112 out of 135 participating countries in 2017. However, Nigeria still ranks low in the Global Competitive Index because of the following reasons advanced by Schwab (2017).

- Lack of strong institutions that should tackle corruption in order to bring sanity into the Nigeria economic system.

- Weak public finance sector due to low margins in the oil sector.

- Weak infrastructures such as inadequate power supply, healthcare, education, low transportation network etc. to encourage investment.

- $\quad$ The widening inequality gap results in more Nigerians falling into absolute poverty in 2018 .

- Macroeconomic instability.

- Low level of I.C.T. due to low investment in technology.

Before concluding Nigeria competitiveness as a result of globalization, factors affecting a country's competitiveness must be evaluated with respect to the Nigeria scenario. According to Kharlamova and Vertelieva, (2013) a country's competitive level depends primarily on keeping the rate of productivity growth greater than or equal to its major competitors. However, Delgado, et al, (2012) maintained that productivity goes beyond normal productivity expectations per employed worker. They stressed further that posterity is ultimately grounded inabilities to achieve high productivity as well as the mobilization of a high share of the workforce. They concluded by stating that the productivity growth rate is directly related to investment in innovation.

Based on the above, it can be argued that most goods and services from Nigerian industries are currently not in a position to compete adequately with products and services from developed countries due to the flawed policies implemented in the economic reform programs in the face of globalization, which are rooted in the liberalization of trade, such as the devaluation of the Nigerian currency, which in turn has forced U. As well, the liberalization of trade has exacerbated the problem of domestic industry where inexpensive commodities imported from technically advanced countries quickly captured the Nigerian market (Bafachwa, Adeboye, \& Bamiro, 1995). In some cases, globalization policy led to factories' outright closure, especially in small scale, less competitive producing industries such as soap, footwear, textile industries, etc. In conclusion, if globalization has fostered trade, it has also discouraged investment in productive activities, leading to a weak competitive situation in developing countries like Nigeria; as such, African countries can expect that competition will be very fierce in both the field of manufactured products and primary products. All the above problems have further weighed down the productivity growth in Nigeria and other developing countries.

Based on the above submission, this study explores why the economic strategies put in place by the government of Nigeria to cub its low global competitiveness has not yielded the desired results. Finally, to proffer suggestions on the specific economic and other related policies adopted by Nigeria to achieve the desired objective of greater competitiveness in the global arena.

\section{METHODOLOGY}

This study is a descriptive analysis where the time-series relationship between the globalization index and Nigeria global competitive index for the periods of 2006 to 2017 are examined. To adequately capture the expected effects of globalization on Nigeria's global economic competitiveness, an econometric model is specified, as shown below. This study's econometric models took their root from the neoclassical theory of effective competition reported by Siudek and Zawojska (2014). A structural autoregressive model in line with Udegbunan, (2002) and Reiss and Wolak, (2007) was specified using annual time series data.

$\mathrm{GCI}=\mathrm{f}(\mathrm{TF}, \mathrm{TO}, \mathrm{GLOB})$

$Y=\beta_{0}+\beta_{1} X_{1}+\beta_{2} X_{2}+\beta_{3} X_{3}+$ et

Please cite this article as: Obomeghie, M. A. ., \& Ugbomhe, U. O. (2021). Globalization and Its Brunt on Nigeria Global Economic Competitiveness: The Need for Holistic and Dynamic Strategies. International Journal of Social Sciences and Economic Review, 3(1), 1-06. doi.org/10.36923/ijsser.v3i1.77 
$\mathrm{GCI}=\beta_{\mathrm{o}}+\beta_{1} \mathrm{TR}+\beta_{2} \mathrm{TO}+\beta_{3} \mathrm{GLOB}+$ et

Where:

$T R=$ Trade Freedom index, which measures the absence of tariffs and other barriers that affect the international trade of goods and services, is used as one of the study's explanatory variables because trade liberalization is a cardinal determinant of global economic competitiveness.

$E F=$ Index of economic freedom, which measures Rule of Law; Limited Government; Regulatory Efficiency and Open Markets is used in the study as one of the explanatory variables financial freedom gives rise to increase competition in the global arena. The overall economic freedom is scored on a scale of 0 to 100 , where 100 represent the maximum freedom.

GCI= Global Competitiveness index, which is composed of 12 pillars of competitiveness represents the basic requirements (Institutions, Infrastructure, Macroeconomic Stability, Health and Primary Education); Efficiency enhancers (Higher Education and Training, Goods Market Efficiency, Labour Market Efficiency, Financial Market Sophistication, Technological Readiness, Market Size), and Innovation and sophistication factors (Business Sophistication, Innovation).

$G L O B=$ GlobalizationIndex represents an average of the indexes for Economic Globalization, Social Globalization, and Political Globalization for all countries, including Nigeria.

Microfit 5.1 econometric software package was utilized in the analysis. The study assumed that time series data collected from the Nigeria statistical bulletin and other statistical agencies are free from bias, given that they were collected from third parties.

\section{RESULTS/ ANALYSIS}

The data collected for the study was estimated using the least square method by utilizing E-views econometric packages to analyse the interaction of the selected variables. Other test statistics, such as the Unit Root test was carried out to ensure the Stationarity of the dataset and the data were stationary at first difference. To avoid the problems of serial correlation among the selected variables, the Jacho-Bera test was conducted. The Johansen test was conducted to test for the long-run relationship among the variables. Finally, the Granger Causality test was conducted to determine a causal relationship between the variables. The results did not show any causal relationship between the selected variables. The estimated yield from the eview output is presented in Table1below.

Table 1

Summary of the OLS regression analysis on $\mathrm{GCI}(N=13)$

\begin{tabular}{llll}
\hline Variable & B & SE $\boldsymbol{\beta}(\mathbf{p r o b})$ \\
\hline Constant & 8.29 & 1.87 & $.01^{*}$ \\
\hline Trade freedom & 0.43 & 0.02 & $.01^{*}$ \\
\hline Globalization & -0.06 & 0.03 & $.04 *$ \\
\hline Economic Freedom & -0.19 & 0.03 & $.01^{*}$ \\
\hline $\mathbf{R}^{2}$ & .84 & & \\
\hline $\mathbf{F}$ & $20.33^{* *}$ & &
\end{tabular}

Note: all values are rounded up to 2 decimal places. $* P<.05 . \quad * * P<.01$

The estimated result reveals that Trade Openness $(\beta=0.01, \mathrm{P}<.05)$. Globalization $(\beta=.49, \mathrm{P}<.05)$, and economic freedom $(\beta=0.01, \mathrm{P}<.05)$ were statistically significant predictors to Nigeria economic competitiveness. The overall model fit is $\mathrm{R}^{2}$ $=.84$. The F- the value of $20.33(\mathrm{P}<.01)$ indicated that our model is adequate for the analysis. The results show that trade openness is significantly and positively impacted on the global competitive index within the period under review. However, globalisation and economic freedom both negatively impacted Nigeria's global economic competitiveness in line with earlier studies by Ayenagbo, et al, (2012) One may observe that globalization and trade freedom entered the analysis with a one-year lag because Nigeria data on globalization and trade freedom rely heavily on the output of previous periods.

\section{DISCUSSION OF The STUDY}

Globalization has presented a serious challenge to developing economies' economic competitiveness, such as Nigeria; thus, estimating the effect of globalization on Nigeria's global economic competitiveness is important because scholars have shown that globalization has had a mixed impact on developing countries' competitiveness. The empirical result supports the study's hypothesis, which states that Nigeria's integration into the global economy has reduced its economic competitiveness. This study's findings are in line with previous works by Kendell (2008), and Ayenagbo, et, al, (2012). This is partly because the influx of superior products from the developed countries has resulted in the disappearance of local products due to better economies of scale and specialisation by the developed countries.

The practical implication of this study's findings is that Nigeria should improve its global economic competitiveness to obtain the benefit associated with globalisation. To achieve this feat, Nigeria should improve on its investment in innovation as well as improvements in other social development factors such as education, health etc., that will ensure that the country's productivity is equal or greater than its competitors. 


\section{CONCLUSION}

Without a doubt, there is an existential challenge for developing countries to gear up and build their capacity to confront the apparent negative reality of globalisation on their competitive ability rather than choosing to remain the victims of globalization. This work has accomplished its stated objective, which is to investigate why Nigeria has performed poorly in global economic competitiveness by carefully investigating how globalization has been identified as the primary culprit of Nigeria's low economic competitiveness globally. From this perspective, Nigeria needs to develop holistic and dynamic strategies through innovation and creativity, good governance, transparency and accountability, which are the panacea for a genuinely competitive economy globally. To achieve this feat, Nigeria should place more emphasis on research and development, encourage investment in innovation, and improve other social development factors such as education, health, etc.

\section{LIMITATIONS AND FUTURE RECOMMENDATIONS}

This study's main limiting factor arises from the fact that the data used in the study were secondary data adopted by the authors from various governmental and international statistical agencies with some degree of extrapolation. The study is also limited to the data analysis method adopted in the study, which is the simple linear regression equation. However, one may also note that global competitiveness is an aspect of globalisation that has not been favourable to developing countries such as Nigeria. Other aspects of globalisation, such as political globalization, may have positively impacted developing countries' social-political life. It is hereby recommended that a study simultaneously assess and estimate social, economic and political globalisation on developing countries may be examined to determine its aggregate impact in one study.

\section{REFERENCES}

Alleynea, A., Francis, B., \& Best, A. (2016). Globalization and International Competitiveness: The Case of CARICOM. Corpus ID 204839122. https://ssrn.com/abstract=2956746

Ayenagbo, K.., Rongchen, W., Wengjing, W., Nguhi, S., Kimatu, J. N., \& Patrick, M.J. (2012). The impact of globalization on African countries economic development. African Journal of Business Management (44): 11057-11076. DOI.10.5897/AJBM12.856

Bafachwa, M.S.D, Adeboye, T.O. \& Bamiro, O.A. (1995). Effects of reforms on technology capability in Sub-Saharan Africa: A conceptual framework. African Technology Policy Studies Network (ATPS) Working no 1, Nairobi (Kenya). ISBN137978-996616976

Delgado, M., Ketels, C., Porter, M. E., \& Stern, S. (2012,). The determinants of national competitiveness. NBER Working Paper Series. DOI:10.3386/w18249

Kendall, P. (2008). Globalisation and the Caribbean. Bridgetown: Caribbean Development Bank. Corpus ID 38386240

Kharlamova, G. \& Vertelieva, O. (2013). The International Competitiveness of countries: Economic-Mathematical approach. Economics and sociology. 6(2) 39-53. DOI: 10.142541/2071-789X2013/6-2/4.

Konyeaso, U.F. (2016). Impact of globalization on Nigerian economy. Pyrex Journal of Business and Finance Management Research. 2 (10), 109-121. ISBN 2985-8860

Kumar, N., \& Pradhan, J. (2002). "FDI, externalities and economic growth in developing countries: Some empirical explorations and implications for WTO negotiations on investment," RIS Discussion Paper No. 27 / 2002. New DelhiIndia.RIS-DP\#27/2002

Kuper, A., \& Kuper, J. (1996). The Social Science Encyclopaedia (2 ${ }^{\text {nd }}$ ed.). Routledge. ISBN 9780415476355

Maddison, A. (2001). The world economy: A millennial perspective. Organization for Economic Cooperation and Development (OECD) Development Centre Study. ISBN-13:978-9264186088

O'Rourke, K. H., \& Williamson, J. G. (2001). Globalization - Then and Now: Review of globalization and history. Review of Income and Wealth, 47(4), 549-559.DOI:10:1111/1475-4991.00034

Reiss, C. P. \& Wolak, A. F. (2007). Structural econometric modelling rationales and examples form industrial organization. Elsevierr, Handbook on Econometric. (6A) 4277 - 4415. https;//doi.org/10.1016/51573-4412 (07)06064-3

Schirato, T., \& Webb, J. (2003). Understanding Globalization. London: Thousand Oaks, California: Sage Publishers. ISBN 07619-4793-0

Schwab, K (2015). The Global Competitiveness Report 2015-2016.Geneva Switzerland. ISBN-13: 978-92-95044-99-9

Schwab, K. (2017). The global competitiveness report 2017 - 2018. Geneva, Switzerland. ISBN-13:978-1-944835-11-8

Shamgquan,G. (2000). Economic globalization; trends, risks and risk prevention. CDP Background Paper No 1. ST/ESAY 2000/CDP/1.

Siudek, T. \& Zawosjska, A. (2014). Competitiveness in the economic concepts: theories and empirical research. Oeconomia 13 (1) 91-108 Corpus ID 59063696 ISSN 1644-0757

Udegbunan, R.I. (2002). Openness, stock market development and industrial growth in Nigeria. The Pakistani development reviews. 41 (1) 69-92.

Umaru, A., Hamidu, A. A. \& Musa, S. (2013). Globalization and its impact on the performance of the Nigerian Economy MPRA Paper No. 75231. Munich. Germany. https://mpra.ub.un-muenchen.de/75231

UN, R (2008). Nigeria living in poverty rise to 61\%. ,https://www.bbc.com/news/world /africa.17015873

UNDP, R (2002). The Global Competitiveness Report. New York: Oxford University Press. ISSB 0-19515981-0

UNIDO, R (1996). The Globalization of Industry: Implications for Developing Countries Beyond 2000, Vienne, Autriche. UNIDO (02)G565. https://www.unido.org/sites/default/files/2009-02/1996\%20UNIDO\%20Annual\%20Report_0.pdf

Please cite this article as: Obomeghie, M. A. ., \& Ugbomhe, U. O. (2021). Globalization and Its Brunt on Nigeria Global Economic Competitiveness: The Need for Holistic and Dynamic Strategies. International Journal of Social Sciences and Economic Review, 3(1), 1-06. doi.org/10.36923/ijsser.v3i1.77 


\section{Author's Biodata:}

Dr Ugbumhe O. Ugbomhe: Dr Ugbumhe O. Ugbomhe is the Acting Head of Department of Business Administration, Faculty of Management Sciences, Ambrose Alli University, Ekpoma, Edo State, Nigeria. He received his doctoral degree in Management from Ebonyi State University Abakaliki, Nigeria. He lectures various courses in Business Administration and Management discipline at Undergraduate and Postgraduate levels.

Dr Muhammed Adamu Obomeghie: Dr Muhammed Adamu Obomeghie is the Dean, School of Information and Communication Technology, Auchi Polytechnic, Nigeria. He received his doctoral degree in Economic Statistics from the International University Cameroun. He lectures Applied Econometrics and Socioeconomic Statistics at the Higher National Diploma level. His research interest includes Economics of Migration Economic modeling. 